\title{
Правописна компетентність як елемент професіограми викладача лінгвістичних дисциплін
}

\author{
I. М. Хом'як, Х. М. Карповець \\ Національний університет «Острозька академія», Острог, Україна \\ Corresponding author. E-mail: khrystyna.karpovets@gmail.com
}

Paper received 13.01.20; Accepted for publication 29.01.20.

\section{https://doi.org/10.31174/SEND-PP2020-219VIII87-05}

\begin{abstract}
Анотація. У статті розглянуто правописну компетентність як складник професіограми викладача лінгвістичних дисциплін. Правописна компетентність у структурі професійної мовнокомунікативної компетентності філолога належить до складу кількох «підсистем» (правописна компетентність $\rightarrow$ мовна компетентність $\rightarrow$ професійна мовнокомунікативна компетентність) $\mathrm{i}$ сама $є$ складним утворенням, яке містить когнітивний, операційний, діяльнісний, ціннісно-смисловий і поведінковий компоненти. Наукова розвідка розкриває феномен мовлення у зв'язку з розгортанням правописної навички. Ї̈̈ вироблення передбачає перетворення зовнішнього мовлення у внутрішнє, коли відтворення образу слова відбувається автоматично, а власне мовний процес залишається за межами свідомості.
\end{abstract}

Ключові слова: правописна компетентність, професіограма, мовлення, мислення.

Вступ. Активна перебудова українського суспільства 3 орієнтуванням на європейські стандарти, сучасні тенденції розвитку освітньо-виховної галузі зумовлюють потребу у висококваліфікованих спеціалістах, готових до самоосвіти й постійного самовдосконалення та здатних творчо й ефективно працювати в динамічних умовах професійної сфери. Діяльність викладача вищої школи залежить від багатьох внутрішніх і зовнішніх чинників, що в підсумку визначають рівень його фахової підготовки та професійної майстерності. Нинішня мовна ситуація, упровадження компетентнісного підходу в навчанні, гуманізація та гуманітаризація освіти вимагають перегляду кваліфікаційних характеристик та освітньо-професійних програм підготовки філологів, уточнення структури професійної компетентності й професіограми викладача лінгвістичних дисциплін, що й зумовлює актуальність теми наукової розвідки. 3 іншого боку, граматичний напрям у навчанні правопису передбачає свідоме запам'ятання орфографічних і пунктуаційних правил та формування відповідних умінь i навичок. Складність мовного матеріалу і часто безсистемність правописних правил створює потребу 3'ясувати значення психолінгвістичного феномену мовлення та індивідуальних особливостей мислення, пам'яті й уваги у процесі вироблення правописної компетентності.

Короткий огляд публікацій. Професіографічні вимоги до викладача вищої школи аналізують С. Вітвицька [2], А. О. Вітченко й А. Ю. Вітченко [2], О. Гура [5], 3. Мірошник і I. Талаш [9]. Однією з основних характеристик викладача-філолога $є$ професійна мовнокомунікативна компетентність, схарактеризована в дослідженнях К. Климової [8], Т. Симоненко [12]. Будову мовної компетентності, зумовлену рівневим поділом мови, описує Н. Мордовцева [10] і виділяє 3поміж інших правописну компетентність, на формування якої впливають лінгвістичні, педагогічні та психологічні чинники. Психологічні аспекти мови й мовлення, без урахування яких неможливо описати процес формування правописної компетентності, висвітлюють дослідження Л. Виготського [1], П. Гальперіна [4], Л. Засєкіної [7], М. Скотта [14].

Мета. Незважаючи на численні дослідження процесу формування професійної компетентності та ії̈ струк- тури, відкритим залишається питання про значення правописної компетентності в системі фахової підготовки майбутніх філологів. 3 огляду на вищезазначене ставимо за мету проаналізувати місце правописної компетентності в структурі професіограми викладача лінгвістичних дисциплін, для чого сформулюємо низку завдань: 1) вивчити складники професіограми викладача-філолога; 2) з'ясувати місце правописної компетентності у структурі професіограми викладача лінгвістичних дисциплін; 3) проаналізувати структуру правописної компетентності, схарактеризувати лінгвістичні, педагогічні та психологічні чинники, які впливають на ii формування; 4) вивчити зв'язок мови й мовлення 3 процесом формування правописної компетентності.

Матеріали й методи. У ході роботи було використано теоретичні методи наукового дослідження, що передбачали аналіз психолого-педагогічної, лінгвістичної і методичної літератури за темою розвідки, узагальнення опрацьованих наукових положень, характеристику професіографічних ознак викладача лінгвістичних дисциплін, виокремлення й опис лінгвістичних, педагогічних та психологічних факторів, від яких залежить процес вироблення правописної компетентносTi.

Результати дослідження. Змістові й функційні особливості певної професії, а також вимоги до фахівця певної сфери діяльності розкриває професіограма, яку пояснюють як «зумовлену змістом праці систему інформації про соціально-економічні, технологічні, санітарно-гігієнічні й педагогічні аспекти професії, іiї психологічні і психофізіологічні властивості та якості, що необхідні й достатні для успішного опанування й ефективного виконання конкретної професійної діяльності» [6, с. 740]. Як зазначають у статті А. О. Вітченко та А. Ю. Вітченко, систематизований опис ідеальної моделі викладача охоплює характеристики спеціаліста за основними напрямами фахової діяльності на певному етапі професійного розвитку (компетентність - професіоналізм - майстерність), умови їх набуття, розвитку й удосконалення та критерії оцінювання (курсив $-X . K$.) [3, с. 175]. У нашому дослідженні більше уваги зосередимо на професійній компетентності, що $є$ складним інтелектуальним, професійним та особистісним утво- 
ренням, яке проявляється й удосконалюється в професійній діяльності [11, с. 4].

Щоб з'ясувати місце правописної компетентності у структурі професіограми викладача лінгвістичних дисциплін, схарактеризуємо кінцевий результат навчання - професійну мовнокомунікативну компетентність. На думку К. Климової, «це інтегрована особистісна якість, що передбачає: 1) систематизовані знання про мову як найвище надбання цивілізації; 2) знання правил мовного спілкування; 3) знання норм сучасної української літературної мови, уміння й навички оптимального використання цих знань у професійному спілкуванні, спроможність до рефлексії, розвинуте «чуття мови»; 4) уміння і навички правильної побудови зв'язних текстів, зумовлених потребами професійної комунікації; 5) уміння користуватися інформаційно-довідковими джерелами для українськомовного самонавчання і caмовдосконалення» [8, с. 21].

Погоджуємося 3 міркуваннями Т. Симоненко, яка до складу професійної мовнокомунікативної компетентності зараховує предметну, прагматичну, технологічну й мовну професійні компетентності [12, с. 45]. Предметна професійна компетентність передбачає наявність фахових знань у системі філологічних дисциплін та вміння застосовувати їх у професійному мовленні. Прагматична професійна компетентність опирається на складники дискурсивної компетентності й означає вміння будувати логічні, послідовні й цілісні професійні висловлювання (дискурси) відповідно до умов комунікативної ситуації. Технологічна професійна компетентність - це здатність чітко й виразно висловлювати думку $з$ дотриманням законів техніки мовлення (правильне дихання, адекватна висота, гучність, гнучкість голосу, відпрацьована дикція, дотримання норм орфоепіi) й урахуванням позамовних засобів. Мовна професійна компетентність передбачає знання мови й дотримання норм літературного мовлення, уміння оперувати мовними засобами і стилістично правильно й доречно використовувати їх.

Мовна компетентність, структуру якої зумовлює будова самої мови як рівневої системи, складається з фонетичної, правописної, лексичної, граматичної та інших компетентностей, тому зміст мовної компетентності полягає в засвоєнні категорій та одиниць мови, вивченні системно-структурних утворень семантичного, синтаксичного, морфологічного, фонологічного характеру, необхідних для розуміння й побудови мовлення [10, с. $115-116]$.

3 огляду на вищезазначене, можна стверджувати, що в професіограмі викладача лінгвістичних дисциплін правописна компетентність - одна 3 характеристик спеціаліста, оскільки вона є субкомпетентністю мовної компетентності, яка, своєю чергою, належить до структурних елементів професійної мовнокомунікативної компетентності філолога. Для кращого розуміння специфіки формування правописної компетентності, охарактеризуємо іï як утворення, у складі якого є: 1) когнітивний; $\quad$ 2) операційний; $\quad 3$ діяльнісний; 4) ціннісно-смисловий; 5) поведінковий компоненти.

Когнітивний компонент містить теоретичні знання з орфографії та пунктуації української мови, що полягають у володінні відповідним термінологічним апаратом та нормами чинного правопису. На основі цих знань та операцій із застосування вивчених правил студенти здійснюють відповідні дії, які в лінгводидактиці називають правописними вміннями. Правописна компетентність майбутніх філологів передбачає сформованість таких умінь: 1) знаходити й розпізнавати орфограми та пунктограми в написаному тексті, розрізняти ïx види; 2) 3'ясовувати вживання орфограм і пунктограм; 3) користуватися словниками для перевірки правильності написань; 4) грамотно оформлювати писемне мовлення 3 урахуванням орфограм i пунктограм; 5) знаходити й виправляти орфографічні та пунктуаційні помилки у своєму та чужому тексті.

Доведені до автоматизму вміння, пов'язані з засвоєнням комплексу знань і їх застосуванням на письмі, перетворюються в правописні навички. Правописні вміння і навички утворюють другий компонент правописної компетентності - операційний, що пов'язаний із третім - діяльнісним, суть якого полягає в застосуванні знань, умінь і навичок на практиці, тобто передбачає хоча б мінімальний досвід використання вивченого матеріалу.

Ціннісно-смисловий складник містить потреби, мотиви та інші ціннісні орієнтири, які передбачають усвідомлення важливості грамотного письма, вміння належно оцінити власний рівень грамотності та працювати над підвищенням рівня сформованості правописної компетентності.

Практично спрямований поведінковий компонент, як логічне втілення нематеріального ціннісносмислового складника правописної компетентності, передбачає усвідомлювані дії - вчинки й демонструє результат установки, що проявляється в постійній роботі над покращенням культури писемного мовлення, дотриманням правописних норм у кожній комунікативній ситуації (написання реферату, оформлення документа, листування в соціальній мережі тощо).

Правопис української мови охоплює орфографію, i пунктуацію, тому відповідна компетентність передбачає належний рівень знань, умінь та навичок 3 обох згаданих розділів мови. Формування правописної компетентності залежить від багатьох лінгвістичних, педагогічних і психологічних чинників.

Теоретичну основу українського правопису становлять принципи орфографії та пунктуації. Найбільш поширеною і загальновідомою є класифікація, за якою до орфографічних принципів належать фонетичний (передбачає написання слова згідно 3 літературною вимовою), морфологічний (полягає в тому, що написання морфеми не залежить від вимови й залишається однаковим у різних словах чи формах того самого слова, тому передбачає добір спільнокореневих слів для «ідентифікації» сумнівних орфограм), традиційний (зумовлює написання слова за традицією), смисловий (регулює розрізнення смислу слів та словосполучень). Описані принципи дають можливість зробити висновок про тісний зв'язок у вивченні орфографії з іншими структурними рівнями мови. Процес формування орфографічної навички відбувається на основі мовленнєвої діяльності, тому під час засвоєння відповідних норм важливо враховувати особливості вимови конкретного слова та його граматичних форм. 3 іншого боку, грамотність залежить від розуміння змісту написаного, що 
доводить необхідність усвідомлювати значення нових слів.

Розставляння розділових знаків у певній синтаксичній конструкції зумовлюють принципи пунктуації. За синтаксичним принципом наявність певного розділового знака диктує структура самого речення, тобто розділові знаки $є$ виразниками синтаксичних зв'язків. За змістовим принципом розділові знаки вживають 3 урахуванням смислових відношень між окремими елементами речення. Суть інтонаційного принципу полягає в тому, що наявність певного розділового знака зумовлена інтонацією синтаксичної структури. Утім, вивчення пунктуації неможливе без урахування всіх трьох принципів, між якими існує тісний міжсистемний зв'язок.

Педагогічний аспект формування правописної компетентності передбачає: 1) володіння відповідним науково-теоретичним апаратом (знання й розуміння термінів орфографія, орфограма, типи орфограм, орфографічне правило, принципи правопису, пунктуація, розділовий знак, пунктограма, пунктуаційне правило, принципи пунктуації тощо); 2) урахування загальнодидактичних і специфічних принципів навчання (до перших належать принципи активності, свідомості й міцності знань; принципи науковості, систематичності й послідовності, наступності й перспективності, доступності, наочності; принципи зв’язку теорії з практикою, навчання 3 вихованням, навчання 3 життям; до других - свідомість і автоматизм під час вивчення орфографії; зв'язок орфографії з граматикою; зв'язок орфографії та пунктуації з розвитком мовлення й мислення; зв'язок пунктуації із синтаксисом; зв'язок пунктуації з виразним читанням; міжкультурний (міжмовний) зв'язок); 3) вироблення системи методів, прийомів, способів і форм роботи, найбільш ефективних у процесі засвоєння відповідного розділу мовознавчої науки.

Висвітлення психологічного аспекту формування правописної компетентності передусім потребує 3'ясування суті понять «мова» і «мовлення». Сьогодні ми розуміємо мову як це систему знаків, що $є$ засобом людського спілкування й розумової діяльності, а також способом самовираження особистості. Л. Засєкіна [7] пояснює мову як систему словесних знаків, спільних для всіх членів соціуму, регулятор діяльності, засіб комунікації, що допомагає оформлювати й формулювати думки, передавати й узагальнювати суспільноісторичний досвід.
У контексті правописної компетентності опишемо передусім писемне мовлення, яке вимагає чіткого й послідовного викладення думок, дотримання правил правопису й граматики, добору відповідних лексичних засобів. Таке мовлення є зовнішнім, оскільки спрямоване на спілкування $з$ іншими людьми. На противагу йому, внутрішнє мовлення не передбачає контакту 3 іншими особами. Людина використовує таку форму мовлення під час міркування, планування, обдумування чогось, не висловлюючись уголос і не записуючи. Зовнішнє мовлення - це процес перетворення думки у слова, іiі матеріалізація, внутрішне - зворотній процес, спрямований зовні всередину, процес «випаровування мовлення в думку» [1, с. 316].

Внутрішнє мовлення є тимчасовим сигналом [13], воно скорочене й уривчасте, оскільки людині, яка думає, відомо, про що йдеться. Внутрішнє мовлення - це внутрішня копія зовнішнього голосу, прогноз звуку голосу, який генерує моторна система [14]. На думку П. Гальперіна [4, с. 26] внутрішнє мовлення - це прихований мовний процес, який не можна виявити ні самоспостереженням, ні реєстрацією мовно-рухових органів. Для власне внутрішнього мовлення характерний безпосередній зв'язок звукового образу слова 3 його значенням і автоматичним протіканням, за якого власне мовний процес залишається за межами свідомості. Таке мовлення з'являється на останньому етапі формування розумових дій, коли мовний процес стає автоматичним, виходить із свідомості, стає у повному розумінні внутрішнім.

Висновки. Отже, правописна компетентність, як субкомпетентність мовної та відповідно професійної мовнокомунікативної компетентності філолога, у структурі професіограми викладача лінгвістичних дисциплін є однією з характеристик спеціаліста. Вироблення правописної компетентності залежить від комплексу лінгвістичних, педагогічних і психологічних чинників. Важливе значення у процесі становлення правописної компетентності має мовлення, оскільки процес розгортання правописної навички передбачає перетворення зовнішнього мовлення у внутрішне, за якого відтворення образу слова відбувається автоматично, а власне мовний процес залишається за межами свідомості. Перспективним уважаємо дослідження інших ланок мовної компетентності в структурі професіограми викладача лінгвістичних дисциплін.

\section{ЛIТЕРАТУРА}

1. Выготский Л. С. Мышление и речь//Собрание сочинений в 6 т., М.: Педагогика, 1982, Т 2, 504 с.

2. ВітвицькаС. С. Професіограма як модель магістра освіти//Педагогічні науки: теорія, історія, інноваційні технології: науковий журнал, 2010, № 8 (10), С. 211-224.

3. Вітченко О. А., Вітченко А. Ю. Проектування професіограми викладача вищої школи для системи неперервної педагогічної освіти//Збірник наукових праць Військового інституту Київського національного університету імені Тараса Шевченка, 2017, Випуск 55, С. 174-180.

4. Гальперин П. Я. К вопросу о внутренней речи//Хрестоматия по педагогической психологи/сост. А. И. Красило, А. П. Новгородцева, Москва: Международная педагогическая академия, 1995, С. 23-31.

5. Гура О. I. Професіограма викладача вищого навчального закладу як основа його професійної підготовки//Социальные технологии. Актуальные проблемы теории

и практики. Международный межвузовский сборник научных робот, 2007, Вып. 36, С. 83-92.

6. Енциклопедія освіти/гол. ред. В. Г. Кремень, К.: Юрінком Інтер, 2008.

7. Засєкіна Л. В., Засєкін С. В. Вступ до психолінгвістики, Острог: Видавництво Національного університету «Острозька академія», 2002.

8. Климова К. Формування мовно-комунікативної професійної компетентності студентів нефілологічних спеціальностей педагогічних університетів, автореф. дис. ... д-ра. пед. наук, К. 2011.

9. Мірошник 3. М., Талаш О. І. Побудова професіограми викладача вищої педагогічної школи: рольовий підхід//Збірник наукових праць К-ПНУ імені Івана Огієнка, Інституту психології імені Г. С. Костюка НАПН України «Проблеми сучасної психології», 2014, Випуск 23, С. 413 425. 
10. Мордовцева Н. В., Компетентнісний підхід до формування мовної особистості молодшого школяра//Вісник Луганського національного університету імені Тараса Шевченка. Педагогічні науки, 2013, № 13 (272), Ч. III, С. 114-119.

11. Савченко К. Ю. Формування професійної компетентності майбутніх учителів філологічних спеціальностей засобами моделювання педагогічних ситуацій//Science and Education a New Dimension, Будапешт, 2013, Ч. 2, С. 3-7.
12. Симоненко Т. В. Формування професійної мовнокомунікативної компетенції студентів філологічних факультетів, дис. ... д-ра пед. наук, Черкаси, 2006.

13. Dell G. S., Oppenheim G. M. Insights for speech production planning from errors in inner speech//The handbook of speech production, Boston, MA: Wiley-Blackwell, 2015, P. 404-418.

14. Scott M. Corollary discharge provides the sensory content of inner speech//Psychological science, 2013, Vol. 24, Issue 9, P. 1824-1830.

\section{REFERENCES}

1. Vygotskyi L. S. Thinking and Speech. Collected Works in 6 Volumes. Moskva: Pedagogika, 1982.

2. Vitvytska S. S. Profesiogram as a model of the master of education//Pedahohichni nauky: teoriia, istoriia, innovatsiini tekhnolohii: naukovyi zhurnal, 2010, № 8 (10), S. 211-224.

3. Vitchenko A. O., Vitchenko A. Yu. The projection of a lecturer's professiogram for a system of continuous pedagogical education//Zbirnyk naukovykh prats Viiskovoho instytutu Kyivskoho natsionalnoho universytetu imeni Tarasa Shevchenka, 2017, № 55, S. 174-180.

4. Halperin P. Ia.To the Question of Internal Speech//Khrestomatyia po pedahohycheskoi psykholohyy, Moskva: Mezhdunarodnaia pedahohycheskaia akademyia, 1995, P. 23-31.

5. Hura O. I. Professiogram of a teacher from a higher school as the basis of his professional training//Sotsialnye tekhnologii. Aktualnye problemy teorii i praktiki. Mezhdunarodnyy mezhvuzovskiy sbornik nauchnykh robot, 2007, № 36, S. 8392.

6. The encyclopedia of education/hol. red. V. H. Kremen, Kyiv: Yurinkom Inter, 2008.

7. Zasiekina L. V., Zasiekin S. V. Introduction to psycholinguistics, Ostroh: Vydavnytstvo Natsionalnoho universytetu «Ostrozka akademiia», 2002.

8 . Klymova $\mathrm{K}$. The formation of language-communicative professional competence of students of non-philological specialties in

pedagogical universities, avtoref. ... d-ra. ped. nauk, Kyiv 2011.

9. Miroshnyk Z. M., Talash I. O. The construction of a high teacher's professiogram: a role approach//Zbirnyk naukovykh prats K-PNU imeni Ivana Ohiienka, Instytutu psykholohii imeni H. S. Kostiuka NAPN Ukrainy «Problemy suchasnoi psykholohii», 2014, Vyp. 23, S. 413-425.

10. Mordovtseva N. V. The competency approach in the formation of a pupil's linguistic identity//Visnyk Luhanskoho natsionalnoho universytet imeni Tarasa Shevchenka. Pedahohichni nauky, 2013, № 13 (272), S. 114-119.

11. Savchenko K. Yu. The formation of professional competence of future philological teachers by the modeling of pedagogical situations//Science and education a new dimension, 2013, № 2, S. 3-7.

12. Symonenko T. V. The formation of professional language and communicative competence of students atphilological faculties, dys. ... d-ra. ped. nauk, Cherkasy 2006.

13. Dell G. S., Oppenheim G. M. Insights for speech production planning from errors in inner speech//The handbook of speech production", in M. Redford (Ed.), Boston, MA: WileyBlackwell, 2015, P. 404-418.

14. Scott M. Corollary discharge provides the sensory content of inner speech//Psychological science, 2013, № 24(9), P. 18241830.

\section{Spelling Competence as an Element of Professiogram of a Lecturer in the Field of Linguistic Studies \\ I. Khomiak, Kh. Karpovets}

Abstract. The article focuses on spelling competence as a component of a lecturer's professiogram in the field of linguistics disciplines. Spelling competence in the structure of professional language-communicative competence of a philologist is a part of several «subsystems»: spelling competence $\rightarrow$ linguistic competence $\rightarrow$ professional lingo-communicative competence. It is also a complex formation, which contains cognitive, operational, active, value-semantic, and behavioral components. The current article reveals the phenomenon of speech in connection with the deployment of spelling skills. Its development involves the transformation of external speech into the internal, when the reproduction of a word's image occurs automatically, and the actual linguistic process remains outside the consciousness.

Keywords: spelling competence, professional graphic, speech, thinking. 